\title{
EL DELITO DE PUBLICIDAD ENGAÑOSA EN ESPAÑA: ALGUNAS CONSIDERACIONES POLÍTICO CRIMINALES Y RELATIVAS AL BIEN JURÍDICO PROTEGIDO
}

César Chaves Pedrón*

\section{Resumen}

Las nuevas técnicas publicitarias tienen una mayor capacidad de incidir en el comportamiento del consumidor, lo cual sitúa a este último en clara desventaja respecto de las empresas; si, además, la publicidad es engañosa, el riesgo para los consumidores es elevado y, por ello, se hace necesario incrementar su protección en la misma medida. Tal tutela ha de ser proporcionada por el Estado a través del derecho, pero el análisis de esta necesidad de protección y la determinación de la forma en que ella debe realizarse, supone examinar el papel de las distintas ramas del ordenamiento jurídico a dichos efectos y, en especial, el del derecho penal, cuya intervención debe evaluarse, en primer lugar, desde una perspectiva eminentemente político criminal.

\section{Palabras clave}

Consumidores, derecho penal económico, publicidad engañosa, marketing, delitos patrimoniales, delitos económicos.

\begin{abstract}
The new advertising techniques can influence the consumers' behavior even more than the priors did. Because of that, consumers are in risk, particularly when the information is misleading or false, and this situation justifies improving legal protection. However, the intensity of this protection and the concrete way to do it requires analizing different branches of law, especially, criminal regulation. In this last case, the exam must start by reviewing the criminal policy that sustains the criminalization of misleading or false advertisement.
\end{abstract}

\section{Keywords}

Consumers, white collar crimes, misleading advertising, marketing, economic crimes.

\footnotetext{
*Abogado, Doctor en Derecho, Profesor Asociado de Derecho Penal Universitat de València.
} 


\section{Introducción}

El análisis político criminal del delito de publicidad engañosa requiere partir de unas premisas diferentes a las empleadas en el estudio tradicional de un delito. Por un lado, ha de considerar la evolución hacia un Estado social que, sin dejar de preocuparse por el erario público, debe atender las necesidades de los ciudadanos y esta situación le obliga a intervenir en la regulación de las relaciones comerciales a través del derecho.

Dentro de esa misma evolución social no puede obviarse el extraordinario desarrollo empresarial y del mercado y el libre acceso al mismo; en este contexto, el recurso a la publicidad es necesario. No obstante, las técnicas publicitarias van perfeccionándose y actúan sobre partes de las personas que pueden condicionar su comportamiento, p. ej., la publicidad emocional incide en la parte emotiva y genera necesidades de adquirir productos y servicios de consumo que las personas realmente no precisan.

Ello produce, por lo tanto, una situación de desventaja para los consumidores frente a las empresas y sus técnicas publicitarias que, en últimas, determinan la conducta de los primeros sin que estos se den cuenta. En tal escenario, si, además, la publicidad es engañosa, el riesgo para los consumidores es alto y, por ende, la necesidad de protección mayor.

El análisis de la situación del consumidor frente a la publicidad engañosa permite tomar posición sobre la necesidad o no de protección penal en estos casos, pero esa decisión también requiere de una valoración del bien jurídico protegido. A ello se dedican las siguientes líneas.

\section{Un nuevo contexto}

El punto de partida podemos establecerlo en la transformación del Estado liberal en uno social, debido a la evolución de la sociedad que demanda una mayor intervención del propio Estado (Borja, 2011, p. 187) y en el que la Administración Pública se hace cargo de la gestión de los recursos públicos para garanizar el bienestar de los ciudadanos. Este modelo requiere que el Estado tome las medidas adecuadas para preservar el erario público y asuma las prestaciones necesarias para mejorar la calidad de vida de los ciudadanos (Borja, 2011, p. 188).

El nuevo contexto también impulsa el desarrollo económico según las leyes del libre mercado y la competencia, lo cual permite un mayor acceso a las empresas y, también, libertad a la hora de establecer los precios (Stampa y Bacigalupo, 1980, p. 163). Esta situación puede propiciar un importante desajuste entre las empresas y las otras partes que intervienen en el mercado, en especial, los consumidores.

Los intereses de los ciudadanos con expectativas de adquisición de bienes y servicios de índole económica podrían verse afectados por una actividad empresarial ajena al debido control estatal, es decir, la adecuada injerencia pública en la vida económico-social se requiere para evitar las desigualdades sociales 
y el menoscabo de los intereses de la parte que pueda resultar más afectada. En este sentido, la libre competencia no impide que, desde la perspectiva propia del Estado de derecho, se impongan restricciones (Stampa y Bacigalupo, 1980, pp. 163-164)y, de este modo, garantizar a los ciudadanos el respeto por sus derechos fundamentales ante cualquier exceso (Novoa, 1982, p. 48).

Esta conversión intervencionista del Estado se traduce en la tutela de bienes de carácter colectivo, para proteger esa parte de la sociedad que participa en una economía de mercado, pero con un potencial inferior al de las empresas, vale decir, a los consumidores.

El progresivo cambio del modelo hacia uno de mayor intervención no supone, necesariamente, que la nueva configuración tenga un carácter autoritario, sino que tratará de salvaguardar el verdadero desarrollo de los ciudadanos y el equilibrio social; lo cual puede alcanzarse si el Estado social actúa bajo los límites que impone el Estado de derecho (Mir, 1994, p. 33). Además, la Constitución española (CE) actual propugna por una realidad económica y social justa que refleje la voluntad popular y se corresponda con un verdadero Estado de derecho (Ruiz, 1980, p. 9). En este escenario, la libertad de mercado no es, en sí misma, un valor absoluto, sino que se encuentra, más bien, subordinada a la satisfacción de los intereses generales (Tamarit, 1990, p. 322).

Al tenor de lo expuesto, se puede afirmar que esa mayor injerencia estatal puede revestir diversas formas y, una de ellas, es la orientada a lograr el equilibrio social ya mencionado mediante el derecho.

Llegados a este punto, resulta necesario poner de manifiesto que, cuando la intervención sea desde la perspectiva penal, ella debe obedecer, necesariamente, al principio de intervención mínima. El respeto a dicho postulado es perfectamente compatible con el Estado social y su característica intervencionista ${ }^{1}$; en particular, cuando tal intervención implica, en esencia, la protección de bienes jurídicos fundamentales para el individuo y la comunidad (Martos, 1987, p. 132). No obstante, cualquier tipo de intervención debe limitarse a aquellos supuestos en los que exista un evidente desequilibrio social y un peligro para los cimientos de la sociedad que conforma un Estado de derecho (Martos, 1987, p. 134).

No se aboga, pues, por una economía dirigida, sino por sancionar el mal uso de la libertad que, en materia económica, puedan hacer las empresas en perjuicio de los consumidores u otros competidores (Rodríguez, 1981, p. 711). Al fin y al cabo, se trata de establecer un conjunto de limitaciones a la actividad empresarial con el propósito de tutelar un grupo -los consumidores- que participa en el proceso de producción y distribución de los bienes y servicios que se lanzan al mercado (Aguilera, 1981, p. 581).

${ }^{1}$ Mir (1994, p. 152) pone de manifiesto el peligro que existe por parte del Estado social de comprometer este principio por utilizar el intervencionismo con una finalidad política alejada de los intereses sociales y de confundir la protección debida a intereses colectivos con la intervención penal. 
Estas limitaciones serán más eficaces si se instrumentalizan a través del derecho penal, en concreto, del llamado 'derecho penal económico', que se considera decisivo para cambiar el rumbo de la política económica desde la política criminal (Tiedemann, 1995, p. 33). A lo anterior se añade su pleno respaldo en la CE, en tanto que protege el interés general y está al servicio de todos los ciudadanos (Hormazábal, 1995, p. 195), por ende, de aquellos que son destinatarios de los productos (Ruiz, 1999, p. 34).

No se trata, ahora, de examinar las teorías que dieron lugar al derecho penal económico, sino, más bien, de exponer su definición actual: tradicionalmente, se ha distinguido entre un concepto estricto de derecho penal económico y otro amplio; el estricto lo circunscribe a los delitos que atentan contra la actividad interventora y reguladora del Estado (Martínez-Buján, 2012, p. 19; Novoa, 1982, p. 48) y, el amplio, lo concibe como aquél que se ocupa de las conductas que afectan bienes jurídicos supradindividuales que no atañen directamente a la regulación jurídica del intervencionismo estatal (Martínez-Buján, 2012, p. 20 y Novoa, 1982, p. 45).

La referencia amplia parece la más acertada para responder a las directrices de la Unión Europea (UE) a la hora de elaborar normas de protección en materia económica. Los países pertenecientes a la UE y que, por lo tanto, tienen abiertas las relaciones económicas entre sí, necesitan de una regulación semejante para proteger el tráfico mercantil y evitar el fraude económico en los distintos países (Vervaele, 1991, p. 119). Para ello, se establecen unas líneas que orienten la elaboración de las respectivas normativas de los países miembros (Sieber, 1995, p. 615; Portero, 2004, pp. 486-487).

Tales directrices comunitarias europeas tratan de aproximar las legislaciones de los distintos Estados (Pagliaro, 1995, p. 694) y un claro ejemplo de lo apuntado es la Recomendación 81 del Comité de Ministros, adoptada por el Consejo de Ministros el 25 de junio de 1981, en la cual se fijan unos principios comunes de política criminal contra la amenaza de la delincuencia económica y donde se incluye la protección a los consumidores y a los competidores frente a las conductas de publicidad engañosa (Ruiz, 1999, pp. 35-39).

Por lo tanto, antes que una relación cercana entre las disposiciones penales de los países miembros, parece más apropiado afirmar que se ha ido abriendo paso un derecho penal 'europeizado', pues, tras la expedición de las normas comunitarias, los países miembros deben adaptar sus legislaciones internas, porque, en caso de no hacerlo, sus leyes penales o sancionadoras administrativas podrían ser declaradas nulas por contrariar las disposiciones comunitarias (Nieto, 2008, p. 419). A causa de ello, se han creado normas penales nacionales que se consideran legítimas en supuestos de ataques a bienes jurídicos económicos, aunque sean de corte clásico como, por ejemplo, el patrimonio ajeno (Bottke, 1995, p. 640).

La consecuencia del creciente interés de la UE en la armonización de las legislaciones de sus Estados miembros y su ampliación a toda infracción que afecte, de alguna manera, bienes de índole económica, ha llevado a la doctrina a aceptar el 
concepto de derecho penal económico en sentido cada vez más amplio hasta considerar, no solo los ataques a bienes económicos supraindividuales, sino, también, aquellos que son individuales, pero orientados a la protección de un bien jurídico mediato supraindividual (Martínez-Buján, 2012, p. 67 y 2014, p. 103).

Así pues, una vez sentada esta premisa conceptual, puede resultar paradójico que el llamado derecho penal económico sea la vía para preservar la libertad en el mercado, imponiendo restricciones ante los abusos (Bajo, 1995, p. 64); pero, a estos efectos, conviene tener presente que la regulación de la actividad de las empresas desde una perspectiva mercantil y administrativa no supone la ausencia del derecho penal (Ruiz, 1999, p. 258) y que este último, en ciertos casos, parece necesario para una mejor preservación del tráfico económico.

\section{La publicidad como herramienta fundamental}

La situación expuesta en el apartado anterior es consecuencia del gran desarrollo mercantilista de las sociedades occidentales (Portero, 2004, p. 484) que generó la proyección social delos productos dentro de un ámbito de gran competencia y donde el receptor de tales ofertas parece encontrarse en una situación de inferioridad. La protección que podía ofrecer el Estado liberal se antojaba escasa en una sociedad cada vez más capitalista que predicaba la plena libertad de industria y comercio, proponía la libre iniciativa empresarial dentro de un marco competitivo y, además, consideraba el lucro como impulsor de esta actividad (Novoa, 1982, p. 51).

Según lo expuesto, el desarrollo del capitalismo transforma el modo de trabajo y de venta: en la época precapitalista, la relación entre el productor y el consumidor era prácticamente personal, mientras que en la capitalista se basa en, de un lado, la ausencia de relación personal y, del otro, una oferta multitudinaria e indiferenciada de los productos por parte del fabricante. Este nuevo modo de trabajo y de mercado trae como consecuencia inevitable la utilización de la publicidad (Feliu, 1984, p. 35; Martínez-Buján, 1983, p. 752) que, también en este marco, se beneficia de los avances en materia de las tecnologías de la información (Lafuente, 2014, p. 86).

La idea con la que se parte respecto de la publicidad es positiva, pues se trata de facilitar información a los consumidores sobre los productos y servicios (Royo, 1998, p. 6) y se entiende que la misma es un medio transversal que estructura a la sociedad desde una perspectiva comunicativa y directa en la vida cotidiana (Benavides, 2012, p. 83). En tal sentido, la publicidad es usada en las sociedades capitalistas como un instrumento para dar a conocer a los ciudadanos los productos y servicios de consumo que ofrecen las empresas y, en esa medida, se ha convertido en una herramienta necesaria en una economía de libre mercado (Tallón, 1979, p. 17).

Tal actividad requiere, para aumentar las ventas, que los mensajes publicitarios tengan un gran calado en el consumidor, al punto que se ha llegado a definir la publicidad como "el arte de convencer consumidores" (Bassat, 2013, p. 33). 
Precisamente por ello, este ámbito es cada vez más especializado y recibe una progresiva inversión de recursos para el desarrollo de sus métodos (Santaella, 1981, p. 23).

La publicidad es, entonces, algo consustancial a las economías de mercado (Sierra, 2003, p. 62) ${ }^{2}$ y, para que el mensaje publicitario sea conocido por todos, se apela a la influencia -cada vez mayor- de los medios de comunicación, llamados mass media, cuyo poder y capacidad para influir en la sociedad se deriva de su potencial para llegar a una gran parte de sus miembros (Cuerda, 2001, pp. 196 y 197). Esta posibilidad de distribución general y, en algunos casos, masiva, requiere que la publicidad tenga una vertiente eminentemente convincente; esta premisa tiene una consecuencia inevitable: la publicidad ha dejado de ser accesoria y se ha convertido en un elemento principal con gran influencia en el sistema económico y social.

En un determinado momento, el producto era su propia publicidad, hoy, en cambio, esta última se ha convertido en su propio producto (Baudrillard, 1989, pp. 8-9). Además, hay un tránsito de un esquema puramente mecánico y direccional ${ }^{3}$ a uno sistémico de enorme complejidad que atiende a la interactividad y la interdependencia de los nuevos referentes de la comunicación; se trata de un modelo que persigue representar todo ese conjunto de interrelaciones que existen en los, ahora, más complejos procesos de interacción cultural derivados de las prácticas mediática y publicitaria.

En definitiva, la comunicación y los medios proponen un escenario complejo en el cual se sustituye el modo tradicional de comprender el mundo y en este nuevo panorama intervienen directamente los individuos, las instituciones públicas y las empresas (Benavides, 2014, p. 9).

\section{Las nuevas técnicas publicitarias}

Para que la publicidad pueda cumplir con el papel relevante que actualmente tiene precisa de unas técnicas adecuadas. Hoy, la técnica publicitaria no transmite un mensaje que implique el simple binomio producción-venta, apoyado en una idea de propaganda $a^{4}$, sino que impone una ideología en la cual el individuo pierde la conciencia de la realidad de sus necesidades y se adapta a una nueva filosofía de consumo que reduzca o anule su capacidad crítica (Pignotti, 1976, p. 30).

\footnotetext{
${ }^{2}$ En el mismo sentido apuntaba los avances producidos en la comunicación de masas y la inserción de las campañas publicitarias, Vázquez (1992, p. 926).

${ }^{3}$ Este modelo se basaba en los principios de la lingüística estructural y el conductismo estadounidense, es decir, la direccionalidad del emisor-hablante- respecto a la del receptor -oyente- (Benavides, 2014, p. 9).

${ }^{4}$ Idea relativa a la propagación de ideas con una organización y plan de acción y, con frecuencia, con la puesta en práctica de procedimientos directos. Usada en el ámbito mercantil pero de una forma menos usual que en otros ámbitos como religión, política, filosofía, etc. Así, Haas (1971, p. 14).
} 
Aunque hay quien opina que la publicidad no crea valores sino que los transmite, pues pretende sugestionar para motivar la conducta sin que el consumidor se dé cuenta (Biedma, 1997, p. 62), sí parece que la publicidad contribuye a crear valores -más que a trasmitirlos-, porque incide en la capacidad motivacional del ciudadano para que realice múltiples actos de consumo que, en la mayoría de los casos, podrían considerarse innecesarios, empleando mensajes persuasivos para cambiar sus actitudes (De Diego, 2014, p. 66). Por lo tanto, la publicidad ya no consiste en informar al público sobre las características y el precio del producto, sino que tiene una finalidad ulterior: persuadir a los consumidores para que compren los productos anunciados (Fernández, 1989, p. 58).

Según lo expuesto, se puede afirmar que la vida económica del individuo se establece sobre tres momentos: primero, el de las necesidades, donde se crean deseos y pasiones; segundo, el de los esfuerzos, dirigido a alcanzar el objeto del deseo o satisfacer la pasión; tercero, el de la satisfacción, la cual se consigue tras obtener lo pretendido. La publicidad solo actúa sobre los dos primeros: crea o excita las necesidades, los deseos, las pasiones (que una vez nacidos resultan, en general, progresivos) y minimiza los esfuerzos del individuo para satisfacerlas (Haas, 1971, p. 79).

En definitiva, la publicidad deja de ser una herramienta comercial de las empresas y pasa a ser una forma de racionalidad utilizada en la sociedad como argumento legitimador de comportamientos y estilos de vida. Ya no se la concibe como la simple actividad de hacer anuncios, sino como una verdadera 'industria cultural' que utiliza sus herramientas y recursos para generar discursos sociales que afectan la vida de las personas y, por ende, el consumo que ellas efectúan (Benavides, 2012, p. 82).

\section{El marketing.}

Una de las primeras técnicas para conseguir los fines apuntados, que, además, ayuda a controlar el mercado, es el marketing ${ }^{5}$, el cual fue implantado a mediados del siglo XX y trasladado a Europa desde los Estados Unidos. El marketing supone una mayor creatividad de los mensajes publicitarios a partir de una cierta forma de decir las cosas (breve, concisa, ocurrente y, sobre todo, cargada de información apoyada en imágenes). El éxito de este modelo conviritó a la publicidad en una herramienta no solo para ganar dinero y hacer ganar dinero a las empresas, sino, también, para consolidar modelos de convivencia social (Benavides, 2014, p. 14).

Para alcanzar el fin pretendido, la estrategia de marketing se basa en cuatro principios fundamentales: en primer lugar, la orientación, es decir, la búsqueda de satisfacción del consumidor como objetivo prioritario de una empresa. En segundo lugar, la segmentación, esto es, la división conceptual del mercado en grupos de

\footnotetext{
${ }^{5}$ El Diccionario de la Real Academia de la Lengua Española lo remite a la palabra "mercadotecnia" para definirla como: "El conjunto de principios y prácticas que buscan el aumento del comercio, especialmente de la demanda, y estudio de los procedimientos y recursos tendentes a este fin". Sobre la utilización del marketing en las sociedades industriales, véase Santaella, (1978, p. 413).
} 
consumidores para atenderlos mejor, pues un grupo de consumidores extenso y homogéneo supone una gran dificultad al momento de satisfacer sus intereses.

En tercer lugar, el marketing diferenciado que consiste en vender el producto adaptado a las necesidades de los segmentos en los que se ha divido a los consumidores, en vez de tratar de vender el mismo producto a todos de manera indiferenciada. Y, en cuarto lugar, el posicionamiento, vale decir, proyectar una imagen definida del producto en la mente del consumidor para que este, a la hora de pensar en el mismo, lo haga evocando la marca (Tellis, 2001, pp. 21-31).

El marketing ha servido para el análisis completo del mercado, determinando la viabilidad de los productos según su potencial adquisición por parte de los consumidores (Hansen, 1970, p. 18). Gracias a la utilización de esta técnica, la publicidad camina junto al marketing de una manera indisoluble, estudiando las posibilidades de un determinado producto o servicio en el mercado y generando su demanda en la sociedad.

Esta nueva fórmula utiliza medios más expansivos como la televisión, el cine, etc., para tener una verdadera eficacia y, si a ello unimos las redes sociales y las nuevas tecnologías, en especial la Internet -una herramienta fundamental en nuestro tiempo- que ha generado una comunicación global y masiva (Romero, 2014, p. 150), queda claro por qué su propagación es mucho mayor; todo esto, sin olvidar el alcance internacional de los mensajes con referencias en diferentes idiomas (Álvarez, 2014, p. 133). En este escenario globalizado en el que todos hablan con todos, gracias a las nuevas tecnologías, los mensajes publicitarios pueden llegar a cualquier rincón del mundo y hacer partícipe a cualquier persona (Jiménez, 2014, p. 96). Desde luego, la utilización de distintos soportes técnicos hace más fácil llamar la atención del consumidor y despertar su interés (Gómez, 2014, p. 164).

\section{La publicidad emocional.}

Según la nueva dinámica publicitaria, el consumismo se transmite con una visión basada en una idea de vida, en la mayoría de los casos, absolutamente irreal. Los productos de consumo deben ofrecer a su destinatario la posibilidad de materializar sus expectativas frustradas, identificándolo socialmente, pero, a la vez, diferenciándolo.

Por ello, la moderna expansión publicitaria se caracteriza por la vinculación de psicólogos y sociólogos a las agencias publicitarias, con la finalidad de obtener mayor calado a través de la explotación emocional. Esta vertiente ha dado lugar a los métodos de investigación sicográfica ${ }^{6}$, p. ej., en los Estados Unidos de los años

\footnotetext{
${ }^{6}$ Se trata del sistema publicitario utilizado a principio de los años ochenta del siglo XX en Estados Unidos, en el que se analiza la población dividiéndola en segmentos; una vez se han obtenido los segmentos de población se establecen los perfiles de cada uno de ellos y la campaña publicitaria se canaliza en la explotación emocional del consumidor de cada segmento poblacional que se hubiere establecido (Meyers, 1994, pp. 22 y ss).
} 
ochenta del siglo XX surgió el enfoque sicográfico denominado Values and LifeStyles (VALS), en castellano, 'valores y estilos de vida', el cual establecía categorías de ciudadanos, integrados o no, según que actualizaran su consumo a la nueva idea de vida que se les transmitía a través de la publicidad (Meyers, 1994, p. 25).

La tendencia apuntada se alimenta de la posibilidad actual y de la futura, en otras palabras, no solo se trata de obtener unas importantes ventas de productos en el momento en que los mismos son creados, sino que se persigue una finalidad de consumo sin solución de continuidad; así, se crea una tendencia -empresarialhacia una productividad virtualmente ilimitada, favorecida por la estructura técnica formada y por la necesidad de dar salida a los productos. La mejor manera de conseguir este objetivo es manipulando al consumidor para adaptar su comportamiento a las necesidades del mercado y generar la falsa necesidad de un producto (Lafuente, 2014, p. 91); esto -que las personas actúen sin control consciente sobre sus comportamientos-, no hace falta decirlo, es una de las principales críticas dirigidas al uso de la publicidad (Royo, 1997, p. 96).

La creación de estereotipos y la explotación emocional animó a los consumidores a participar de la vida publicitaria y a demandar que su voz, sus quejas y descontentos fueran oídos (Benavides, 2012, p. 82); sin embargo, pese a las reacciones del consumidor, la publicidad sigue penetrando de forma directa en él, asegurando de este modo que las ventas continúen (Meyers, 1994, pp. 248 y ss.) y, a tales efectos, utiliza la forma más adecuada para interferir en el momento motivacional y asegurar el consumo innecesario que propicia la riqueza emergente de las empresas. Es decir, la evolucionada técnica publicitaria cotinuará gravitando sobre la creación de la imagen social y de la integración en esta sociedad según los actos de consumo que se realicen.

Para influir en la capacidad de decisión de los consumidores, la publicidad debe nutrirse de aspectos psicológicos y sociológicos, además de recurrir a los tradicionales análisis económicos del mercado. La permeabilidad que las personas muestren al mensaje dependerá, en gran medida, de la materialización psicológica que el producto logre en un determinado sector de la población y el acierto de las técnicas publicitarias empleadas está supeditado a que el estímulo utilizado sea el correcto (Ogilvy, 1990, p. 9); para conseguirlo, primero hay que dar con el 'concepto'. El mensaje clave es lo que diferencia el producto de un fabricante del de la competencia (Cuesta, 2014, p. 4), aunque no puede olvidarse que, en últimas, la publicidad que más gusta es la que más vende (Bassat, 2013, p. 40).

Con todo, la publicidad no puede entenderse desde una perspectiva aislada, esto es, como un universo cerrado en sí mismo, sino, más bien, a partir de la estructura social que se ha generado. Con otras palabras, la creación de una sociedad de superlativos tiene como consecuencia que la economía sobreviva creando artificialmente la demanda en lugar de satisfacerla (Pignotti, 1976, p. 32).

A todo lo dicho contribuyen las herramientas que permiten comprobar la eficacia que ha tenido la publicidad lanzada sobre el consumidor, $v$. gr., el estudio de 
audiencias a través de los medios de comunicación (Matellanes, 2014, pp. 115-116). Pero esas técnicas de medición de la eficacia publicitaria van más allá de esto y miden las respuestas de los individuos de forma tal que los especialistas puedan analizarlas. Ello se realiza mediante la utilización de las siguientes técnicas:

- Cognoscitivas: miden la capacidad del anuncio para llamar la atención, el conocimiento y la comprensión del individuo. Esta técnica persigue que el individuo sea consciente de la existencia del producto y de los beneficios que posee.

- Afectivas: miden la actitud que un estímulo publicitario es capaz de generar en las personas para producir un cambio de actitud.

- Conativas: miden el comportamiento de respuesta de las personas no solo en términos de compra, sino también a través de la predisposición a actuar en la dirección que se desea, p. ej., pidiendo más información del producto o acudiendo al punto de venta (Martín, 2014, pp. 178-179).

Por lo tanto, la publicidad juega un papel tan importante que su tendencia actual viene marcada por la creación de ideas sobre un producto, incluso antes de probarlo; evidentemente, nadie conocerá de verdad el producto y sus características y condiciones hasta que lo adquiera. La publicidad trata de crear en la mente una idea relativa a un determinado bien de consumo y, por ello, la vida de dicho producto -de una determinada marca- depende de aquella; tanto, que se ha llegado a afirmar, tal y como ya apuntamos, que la publicidad no es solo parte del producto sino que es el producto mismo (Lorente, 1989, p.15).

Esta nueva forma de llevar a cabo la publicidad descubre su nuevo cometido: ya no trata de mostrar a los consumidores los productos que tiene a su disposición en el ámbito del mercado, sino de transmitirles una idea sobre un determinado producto que permanezca en su cerebro y que el hecho de adquirirlo y disfrutarlo suponga una pertinaz búsqueda de aceptación social ${ }^{7}$. Incluso, se advierte que los consumidores quieren que las marcas les faciliten sus elecciones de compra y, por supuesto, las firmas lo hacen con propuestas revestidas de seducción y afectividad (López, 2007, p. 31); una versión moderada de esta interpretación alude a facilitar la elección mediante la información, el entretenimiento y la confianza (Bassat, 2013, p. 37).

En este marco, la atracción emotiva juega un papel importantísimo en la estimulación del deseo y la determinación de la acción de adquirir (Lester, 1968, p. 45), porque, en primer lugar, bajo una óptica neurológica se considera a las emociones como un conjunto complejo de respuestas químicas y neuronales causadas por un estímulo emocionalmente competente captado por el cerebro que está, gracias a la evolución, preparado para responder a esos estímulos con repertorios específicos de acción (Damasio, 2005, p. 55). En segundo lugar, la reacción emocional

\footnotetext{
${ }^{7}$ La técnica publicitaria en algún momento se ha amparado más en determinadas ciencias - como fue el psicoanálisis en los años setenta y ochenta - que en la propia imaginación de los publicistas (Meyers, 1994, p. 54).
} 
puede tener lugar sin un conocimiento consciente del estímulo emocionalmente competente (Damasio, 2005, p. 57) y, en tercer lugar, una vez desencadenada la emoción, se activan distintas partes de ejecución de emociones en distintos puntos del cerebro (Damasio, 2005, p. 60). Surge, así, la publicidad emocional que trata de persuadir al consumidor a través de sus sentimientos para cubrir deseos y anhelos profundos de manera real o simbólica (López, 2007, p. 32).

La participación de expertos en ventas, estudiosos de los mercados, psicólogos y sociólogos genera la posibilidad de 'crear necesidades's en los consumidores para que adquieran los productos y servicios que se exhiben en el mercado. Como el comportamiento de los consumidores se considera el eje fundamental de la actividad publicitaria, ello explica la utilización de métodos de investigación en psicología centrados en estímulos, respuestas, percepción, atención selectiva, aprendizaje, inteligencia y personalidad y, sobre todo, comportamiento (Guía, 1998, p. 2).

La vida publicitaria comienza, ahora más, a gravitar sobre la idea ya comentada de creación de estereotipos de personas, que adquirirán una mayor integración social con el consumo de determinados productos o servicios o de una cierta marca. La manera de conseguirlo pasa por influenciar emocionalmente a los consumidores que se sienten realizados -en lo que a la integración social se refierepor el hecho de adquirir y disfrutar de determinado producto o marca. Al fin y al cabo, la motivación no está en el producto sino en el interior de la persona (Bassat, 2013, p. 81).

No podemos dejar de mencionar, a raíz de lo expuesto, la enorme contribución a la publicidad emocional que tienen los medios de comunicación, los cuales ponen a disposición del público un mercado de sensaciones a través de imágenes placenteras asociadas a las marcas. Permiten, además, que los destinatarios tengan experiencias emocionales a través de la publicidad, dentro de un espacio mediático que facilita a la sociedad una evasión y el disfrute mediante la emisión de contenidos de fácil recepción (López, 2007, p. 33).

Hay algunos temas de publicidad ligada a los sentimientos, v. gr., el estatus y la admiración (Audi), la pureza y el sentimiento de libertad (Lanjarón), la independencia femenina (Bourjois), la delicadeza y la sensualidad femenina que seduce al hombre (Agua fresca de rosas), el cuerpo perfecto (Giorgio Armani), la vida perfecta sin obligaciones (Once), la eterna juventud (Antiarrugas) o, en fin, ser los mejores (Repsol). Se trata de motivaciones subconscientes y, en este entendido, la publicidad emocional habla de los sueños y emociones de las personas -contenidos de la psique humana-, sirve como instrumento a la sociedad de consumo y utiliza los mensajes publicitarios para generar nuevas necesidades

\footnotetext{
${ }^{8}$ A tal efecto se utiliza la expresión 'creación de necesidades' para transmitir la idea de artificialidad en la sensación despertada en los consumidores sobre la necesidad, para su vida cotidiana, de la adquisición de determinados productos.
} 
en los consumidores que solo podrán ser satisfechas por aquellos que forman el tejido productivo (López, 2007, pp. 140 y 141).

\section{El neuromarketing.}

La técnica publicitaria capaz de generar deseos y necesidades en las personas no se agota en lo expuesto antes, pues, si hablamos de persuasión, no podemos olvidar la última y más reciente tendencia: el llamado neuromarketing.

Se trata de aplicar la neurociencia -el estudio de la localización anatómica de los procesos cerebrales (Muñiz, 2014, p. 193)- al ámbito publicitario. Así, el neuromarketing es una disciplina avanzada que investiga y estudia los procesos cerebrales que explican la conducta y la toma de decisiones de las personas en los campos de acción del marketing tradicional: inteligencia de mercado, diseño de productos y servicios, comunicaciones, precios, branding, posicionamiento, canales y ventas (Braidot, 2000, p. 6). Si esta técnica no está más implantada en publicidad es debido a los elevados costes que supone la participación de personas altamente cualificadas (Muñiz, 2014, p. 190).

A modo de resumen, pueden indicarse las siguientes técnicas:

- Eye-tracker: observa el comportamiento ocular ante una determinada configuración estimular. Con ello se conseguiría determinar qué puntos exactos han sido visualmente atendidos y percibidos.

- Electroencefalograma: mide la actividad eléctrica del tejido neuronal, especialmente el de la corteza cerebral. Con esta técnica se puede detectar la activación que se produce en el neurocórtex ante un determinado estímulo.

- Electrocardiograma: registra la actividad eléctrica del corazón. Con ello se puede observar el ritmo cardíaco ante una situación perceptiva a la que se exponga al sujeto.

- Electromiograma: registra la activación nerviosa que está detrás del control de la musculatura. Esta técnica permite observar una contracción muscular ante una situación estimular y establecer el correlato emocional que dicha situación puede estar provocando, p. ej., en los músculos faciales.

- Respuesta galvánica de la piel: mide el potencial eléctrico de la piel a través de una serie de electrodos colocados en las manos. Recoge el cambio de conductividad de la piel, lo cual es una señal inequívoca de un cambio de nivel de activación psicofisiológica ante un estímulo determinado.

- Imagen por resonancia magnética funcional: registra con mayor precisión la actividad en zonas profundas del encéfalo. Mide milimétricamente todo tipo de cambios de la actividad cerebral asociados a todo tipo de estimulaciones, tanto internas al sujeto como contextuales. 
A partir de las técnicas expuestas, se puede afirmar que todos los procesos psicológicos básicos implicados en la comunicación publicitaria son observables bajo el estudio neurocientífico, empezando por la atención que pueden conseguir los diferentes elementos del mensaje para ser primeramente percibido (Muñiz, 2014, pp. 198 y 199). Los cerebros, no se olvide, están siempre receptivos a un nuevo estímulo (Ratey, 2003, p. 143).

La satisfacción personal del consumidor a la hora de adquirir concluye el proceso orientado a incidir en el momento motivacional de la persona y la publicidad ha sido la encargada de hacerle percibir el producto o el servicio por los sentidos y generar en su mente una idea que le hará persistir en la intención de adquirirlos. De esta forma, se consigue el propósito de no quedarse en una compra aislada e inmediata, pues, las empresas, como parte de una sociedad de mercado y consumista, necesitan la constante generación de expectativas de adquisición para continuar con su más que lucrativa actividad 9 .

\section{El bien jurídico protegido en el delito de publicidad engañosa}

En orden a reflexionar sobre el bien jurídico, y una vez expuestos los argumentos anteriores, es preciso reiterar la idea que ha servido de punto de partida: la situación desventajosa en la que se encuentran los consumidores ante el poder que manejan las empresas; esta afirmación se fundamenta, atendidas las técnicas publicitarias expuestas, en la continua y progresiva, porque no decirlo, manipulación de la masa social en el entorno mercantil, propio de una sociedad eminentemente capitalista y consumista. La desventaja para quien es objeto de dicha manipulación se deriva de la anulación o disminución de su poder decisiorio.

La publicidad abunda, cada vez más, en estereotipos, modelos preestablecidos y, finalmente, hábitos de consumo; tanto es así, que los textos publicitarios no persiguen la comprensión del consumidor, sino, más bien, que cause efecto debido a una presentación atractiva, sugestiva y alusiva (Feliu, 1984, p. 286). La repercusión económica de esta estrategia impacta al consumidor cada vez más, pues los gastos en actos de consumo son mayores y, por ende, también aumentan los posibles perjuicios económicos que pueden generar las conductas ilícitas de las empresas que ponen a disposición de las personas los productos o servicios.

El volumen de estos potenciales daños hace que los consumidores los perciban con mayor facilidad y, por consiguiente, cuando aquellos tienen lugar y se derivan de un comportamiento defraudatorio, cabe esperar una respuesta social orientada

\footnotetext{
${ }^{9}$ Pensemos, para aclarar esta idea, en los avances tecnológicos a nivel informático o de propio entretenimiento. Cuando se adquiere el novedoso ordenador con los nuevos desarrollos técnicos genera la necesidad de adquisición en los consumidores para la realización de su trabajo e incluso comunicación; en poco tiempo se aparece un nuevo progreso técnico que nos hace pensar en lo necesario que es para nuestro trabajo, cuando en realidad no es así, aunque sí es cierto que puede mejorar las prestaciones; pero realmente no es una solución que de verdad sea imprescindible. Aun así, nos han influenciado tanto que se ha generado en nuestra mente la idea de necesidad y de progreso social con la nueva adquisición.
} 
a reclamar una mayor protección, incluso desde la perspectiva penal. Naturalmente, esta demanda de la comunidad presionará al legislador (Arroyo, 1994, p. 15) que, si bien corre el riesgo de utilizar el derecho penal de forma simbólica (Bajo, 2001, p. 408), lo cierto es que, al decidirse por intervenir penalmente, toma una decisión a favor de tutelar a los consumidores.

\section{La necesidad de la intervención penal.}

La intervención penal encaminada a proteger a los consumidores -la parte más débil- se antoja necesaria a la vista de la mayor incidencia de la delincuencia económica (debido a la gran cantidad de dinero que la actividad empresarial genera), la dimensión del perjuicio sufrido por las víctimas de las conductas delictivas y, en especial, del poder de las empresas y las limitaciones de los ciudadanos para hacerles frente.

Ahora bien, si circunscribimos el ámbito de la defraudación económica a los supuestos en los que se ha utilizado la publicidad para causar un perjuicio a los consumidores, porque dicha publicidad es ilícita o, más concretamente, engañosa (Ripoll, 1991, p. 996), y tal proceder viene acompañado del correlativo ánimo de enriquecimiento por parte de las empresas, debemos plantearnos si los mecanismos de defensa creados por el Estado son suficientes para proteger a los ciudadanos. Sin embargo, para tomar una postura sobre la cuestión planteada es necesario analizar la incidencia de la defraudación y del consiguiente perjuicio, así como del ámbito individual o supraindividual de la afectación que genera tal actuación.

El recurso al derecho penal es uno de los muchos instrumentos que tiene el Estado para frenar las nuevas formas de delincuencia -o enfrentar su ramificacióny de evitar los grandes perjuicios que se puedan causar (Tiedemann, 1985, p. 30). Frente a las nuevas modalidades de fraudes económicos y los cada vez mayores perjuicios que estos generan, los Estados han optado por la protección penal, pues las sanciones administrativas posiblemente han resultado ser poco eficaces para combatirlas.

Esto, desde luego, habla a favor de la intervención penal, pero, puestos en este punto, es necesario tener en cuenta que los adelantos y las técnicas desarrolladas en las sociedades contemporáneas conllevan la creación de riesgos más o menos directos para los ciudadanos (Silva, 2006, p. 16) que pueden materializarse en consecuencias lesivas, algunas de ellas a largo plazo. Por ello, los delitos tradicionales- de lesión también se revelan insuficientes para proteger a la sociedad y ello explica el recurso a los tipos de peligro (Silva, 2006, pp. 16-17): si la pena sólo puede imponerse cuando el peligro se materializa en una lesión, es posible que la consecuencia jurídica llegue demasiado tarde para conseguir los mayores efectos preventivos y, por ello, quizás resulta más conveniente situar la intervención penal en un momento anterior a la lesión, es decir, al momento del peligro (Cuerda, 1995, p. 72). 
A lo expuesto hay que añadir dos aspectos más: por una parte, la benevolencia con la que el legislador ha tratado, tradicionalmente, a aquellas personas que cometen delitos de carácter económico y que su represión venía siendo insuficiente (Fernández y Martínez-Buján, 1983, p. 37) y, por la otra, que la publicidad, cuando es engañosa, puede coartar la facultad selectiva de los ciudadanos y es, precisamente, la necesidad de controlar su ejercicio, para evitar abusos, lo que justifica su control jurídico (Tiedemann, 1985, p. 52).

Por lo tanto, si incluso los delitos de lesión tradicionales se manifiestan insuficientes ante los riesgos propios de una sociedad tecnificada de consumo, con mayor razón puede calificarse de escasa la protección otorgada por el derecho administrativo. Las nuevas formas de delincuencia surgidas a propósito del ámbito mercantil y de la utilización de la publicidad, que con sus sofisticadas técnicas sumadas a la ingenuidad del consumidor, convierten a este último en la parte más débil -“el eslabón más débil de la cadena" (Iglesias, 2013, p. 645) -, sugieren la necesidad de acudir al recurso penal para amparar eficazmente los legítimos intereses de los consumidores.

\section{El bien jurídico tutelado.}

\section{Las teorías socioeconómicas.}

Una vez establecida la conveniencia de la protección penal frente a la publicidad engañosa, es preciso referirse al bien jurídico protegido en el artículo 282 del Código Penal español (CP) que, a primera vista, parece ser el derecho de información de los consumidores, pero, por supuesto, a una información veraz sobre los productos y servicios (Carbonell, 1999, p. 524; Martínez-Buján, 1984, p. 69, 1996, p. 1370 y 2015, p. 290; Valle, 1996, p. 637 y Manzanares, 1988, p. 271) ${ }^{10}$. No es ocioso considerar que el bien jurídico tutelado, entendido como ese derecho que tienen los consumidores a la información veraz, es el reflejo constitucional de otros, que específicamente hablan de recibirla así.

Esta propuesta merece ciertas reservas, pues, si bien es cierto que la información veraz sobre los productos o servicios ofrecidos a los consumidores puede tener incidencia en su capacidad de decisión (Carbonell, 1999, p. 524), es evidente que el artículo $282 \mathrm{CP}$ incluye la expresión 'de modo que puedan causar un perjuicio grave y manifiesto a los consumidores', según la cual es preciso que de la información inveraz se pueda derivar algún tipo de perjuicio (Gómez, 1997, p. 1232); contrario sensu, una información inveraz que no pueda causar un perjuicio grave y manifiesto no encajará en el tipo penal.

La referencia a la potencialidad del perjuicio para los consumidores sugiere que se trata de un delito de peligro y, para el caso, de peligro abstracto, en tanto hay una situación peligrosa determinada por el legislador (Cobo del Rosal, 1999,

\footnotetext{
${ }^{10}$ Aunque, Carbonell (1999, p. 524) reconoce que se trata de una infracción socioeconómica, pero de la que no se deben excluir otros derechos como la vida, la salud y la integridad física (González, 1998, p. 148 y Bajo y Bacigalupo, 2001, p. 544).
} 
p. 327; Mir, 1994, p. 208; Barbero, 1973, p. 489; Octavio de Toledo y Ubieto, 1979, p. 83 y Rodríguez, 1994, p. 14). La sanción del peligro abstracto no ha estado exenta de críticas por entenderse que los tipos penales solo deben castigar el peligro concreto, pero esa objeción ha sido desechada argumentando que los delitos de peligro abstracto suponen un adelantamiento de la barrera de protección de los bienes jurídicos en situaciones de potencialidad de lesión y que, por ello, sî deben tener cabida en el ordenamiento jurídico-penal (Barbero, 1973, p. 489; Mir, 1994, p. 209; García, 1998, p. 32; Martínez-Buján, 1992-1993, pp. 340-341 y Cuerda, 1995, p. 72).

Ahora bien, tratándose del delito que nos ocupa, parte de la doctrina exige que la conducta incriminada cause un peligro grave y manifiesto, constituyendo un tipo, dentro de los delitos de peligro abstracto, de los llamados de peligro hipotético. Es decir, un tipo penal que no requiere la producción de un peligro efectivo, pero sí una acción apta para producir un peligro al bien jurídico; una especie de tipo entre el peligro abstracto y el peligro concreto, pero, en todo caso, un subtipo del primero (Torío, 1981, p. 828). En este sentido, el delito de publicidad engañosa, al requerir que la acción pueda perjudicar de manera grave y manifiesta a los consumidores, se ha considerado un delito de peligro hipotético, pues depende de que se verifique la probabilidad del mismo (Martínez-Buján, 1995, p. 233).

Empero, no toda la doctrina comparte esta opción, porque, si el argumento esgrimido es que los delitos de peligro hipotético son aquellos que tienen una aptitud para producir un peligro al bien jurídico, parece válido inferir que los que siguen llamando de peligro abstracto no la tienen. Esta opción, como ya hemos dicho, no es compartida por parte de los autores, en tanto no se puede negar esa aptitud en los delitos de peligro abstracto.

En tales delitos se ha considerado que la peligrosidad de la conducta va implícita en la descripción típica; por lo tanto, es el legislador quien hace la valoración de su aptitud lesiva. Dentro de la misma categoría están los tipos que incorporan elementos normativos de aptitud, cuyo cumplimiento deberá constatar el juez (Rodríguez, 1994, p. 20) ${ }^{11}$, en desarrollo de una actividad probatoria de cargo suficiente (Moreno, 2002, p. 436), para que la conducta sea típica.

Por lo tanto, y como consecuencia de lo expuesto, optaremos por la denominación de delito de peligro abstracto por entender que la única diferencia posible es entre delitos de peligro abstracto y de peligro concreto, tal y como hace buena parte de la doctrina penal (Borja, 1995, p. 147; Orts y González, 2015, p. 247; Mir, 2015, p. 238 y Cobo del Rosal y Vives, 1999, p. 327).

Esto aclarado, y a propósito del peligro, resulta oportuno recordar el marco en el que nos encontramos: un escenario mercantil donde la publicidad es un mecanismo de gran profusión comercial empleado por los fabricantes y los comerciantes que

${ }^{11}$ También cabe destacar quien ha considerado que en los delitos de peligro abstracto hay una peligrosidad estadística que se da con la propia realización de la conducta (Gómez, 2005, pp. 470 y 471). 
arman sus estrategias de venta dirigidas a los consumidores, lo cual genera una situación en la que los intereses de estos últimos, particularmente los económicos, tienen una gran probabilidad de resultar afectados; por ello, en este supuesto, sí parece acertado adelantar la barrera de punición.

Casi sin pretenderlo hemos llegado a otro argumento que refuta la idea de considerar el derecho a una información veraz como el único bien jurídico tutelado en el delito de publicidad engañosa; en efecto, si el bien jurídico fuera el indicado, la sola información inveraz supondría su lesión, pero ocurre que, acorde con la redacción del delito, se requiere la potencialidad de un peligro (Carrasco, 2000, p. 88) $)^{12}$.

El bien jurídico, entonces, debe tener un alcance más amplio (Hernández, 1997, p. 1108), pues, cuando la información desvirtuada $y$, por ende, inveraz, es determinante en la decisión del consumidor, la trascendencia de aquella va más allá de la correcta y libre formación de la voluntad (Carbonell, 1999, p. 524). Una apreciación más amplia del bien jurídico protegido implica considerar que, mediante la publicidad veraz, se forma correctamente la libre decisión del consumidor $\mathrm{y}$, por ello, cabe afirmar que también se protegen los intereses colectivos y no individuales ${ }^{13}$ - de los mismos (Barona, 1999, p. 644; Muñoz, 2015, p. 458; Tamarit, 1990, p. 333; Gómez, 1997, p. 440; De Vega, 1988, p. 281; De Jesús, 1988, p. 315) y, otro argumento a favor de lo afirmado, es que la información veraz es un instrumento para proteger otros derechos como la salud, los legítimos intereses económicos, etc. (art. 51.1 y 2. CE).

Un sector de la doctrina penal apunta que el artículo $282 \mathrm{CP}$ protege, junto a los intereses de los consumidores, los de los competidores, aunque de forma indirecta, en tanto la publicidad engañosa también encaja como publicidad desleal (González, 1995, p. 180 y 2011, pp. 600-6014). En este caso debemos mostrar una firme oposición a esa afirmación, pues, aunque para los competidores puede suponer un beneficio dicha referencia a la publicidad engañosa, esa es una consecuencia indirecta (Barona, 1999, p. 643 y Carrasco, 2000, p. 87), pero no buscada por el legislador como propósito de protección y, en tal medida, no puede constituir el objeto de tutela penal; sobre todo, si encontramos otras normas que velan por la competencia leal.

Es el caso, por ejemplo, de las lesiones a la competencia que tienen lugar mediante la publicidad, pero sin que ella sea engañosa, como cuando un fabricante o comerciante, a través de publicidad no engañosa, compara su producto con el de un competidor exaltando los defectos de éste último [Sentencia del Tribunal Supremo, de 24 de febrero de 1997 (RJ 1195/1997)]. En tales supuestos, hay una

\footnotetext{
${ }^{12}$ En contra, Morales (2011, pp. 886 y 887), para quien el término 'manifiesto' implica algo que ha adquirido concreción.

${ }^{13}$ Entendiendo, algún autor, que los bienes son de carácter individual (patrimonio, vida, salud, etc.) pero de pertenencia y formación colectiva (Mata y Martín, 1997, p. 8)

${ }^{14} \mathrm{El}$ citado autor se inclina, más recientemente, por la protección de los intereses económicos de los consumidores.
} 
infracción a la competencia leal que no encajaría en el artículo $282 \mathrm{CP}$ porque no es publicidad engañosa. Otro tanto puede afirmarse en el supuesto de una publicidad engañosa realizada por una empresa que ostenta una posición de monopolio en el mercado, puesto que ello afectaría a los consumidores y no a los competidores, porque no los habría (Cuerda, 1995, p. 75).

Por consiguiente, si se entendiera que lo protegido son los intereses de los competidores no podríamos dejar por fuera estos supuestos que, sin embargo, quedan excluidos del tipo; entenderlo de otra forma, supondría admitir que a veces se protegen los intereses de los competidores y a veces no.

Lo protegido, entonces, son los intereses de los consumidores. Una vez acotado el objeto de tutela penal en los anteriores términos, debemos adentrarnos en el espinoso camino que lleva a determinar, de forma concreta, qué intereses de los mismos se van a proteger; puesto que una alusión tan genérica parece demasiado vaga para satisfacer los requisitos de configuración del bien jurídico.

En este sentido, como hemos dicho, el derecho a recibir una información veraz para que los consumidores formen libremente su voluntad -como elemento puramente adquisitivo en las relaciones de mercado- debe tener una mayor trascendencia. Por consiguiente, si la publicidad engañosa vicia la voluntad de los consumidores en orden a adquirir los bienes y servicios ofrecidos en el mercado, necesariamente, habrá algún riesgo -conforme lo exige el tipo, un potencial perjuicio grave y manifiesto para los consumidores- que afecte de manera directa algún interés, pero, ¿cuál?

Los autores se encuentran divididos en este aspecto trascendental: en primer lugar, un sector doctrinal se inclina por considerar el interés de los consumidores como puramente económico, apoyado en que la redacción del artículo $282 \mathrm{CP}$ sugiere un vínculo con un bien jurídico de contenido económico, pues los consumidores son una parte de las relaciones comerciales en un modelo socioeconómico de libre mercado (Mapelli, 1999, p. 49; Hernández, 1997a, p. 1109 y y 1997b, p. 258) ${ }^{15}$.

Este aspecto se concreta aún más, diciendo que los delitos socioeconómicos contra los consumidores se dirigen a preservar auténticos intereses difusos de estos y vulneran el interés de ese colectivo en el orden del mercado; así, se configura

${ }^{15}$ Hay quienes consideran que la protección económica de los consumidores se instrumenta
a través de la protección de la información veraz -entendiendo que existe una libertad
de disposición de los consumidores en la contratación de bienes y servicios-, lo cual
refleja, realmente, la protección del interés económico y, por ende, reafirma que el bien
jurídico tiene un carácter socioeconómico (Mapelli, 1999, p. 49; Muñagorri, 1998, p. 73;
Santaella,1981, p. 99; Terradillos, 1995, p. 186); en tal sentido, el examinado sería un delito
contra el orden socioeconómico destinado a la protección de intereses difusos. Ahora bien,
si son delitos contra el orden socioeconómico, entonces afectan los intereses económicos
de los consumidores, aunque se trate de intereses puramente patrimoniales (Hernández,
1997, p. 1.109; García y López, 1996, p. 142; Moreno y Bravo, 2001 , p. 39; Portero, 2004, p.
249); González, 2010, p. 85; Puente, 2002, p. 263; Sierra, 2003, p. 130 y Macías, 2012, p. 211). 
como un bien jurídico 'espiritualizado' o 'instrumentalizado' de índole colectiva con referencia, si bien con matices (Martínez-Buján, 1996, p. 1370), a bienes individualizables (Martínez-Buján, 2015, p. 290).

En el mismo sentido, se añade que se trata de proteger, mediante este bien de carácter colectivo, bienes individuales, singularmente el patrimonio, en orden a garantizar el disfrute de los mismos (Doval, 2012, p. 484). Incluso, en algún momento se cuestionó su pretendida naturaleza supraindividual con base en lo previsto en el CP (art. 87), pero no parece que lo dispuesto allí impida concebirlo en dicha clave (Vidales, 1998, p. 345).

También cabe destacar la opinión que lo considera de carácter económico, gracias a su ubicación sistemática (Sánchez, 1997, p. 565; Demetrio, 2005, pp. 170-171), pues la misma es reveladora del objeto de protección: si el delito se ubica dentro de los delitos contra el patrimonio y el orden socioeconómico y, particularmente, en el grupo de los delitos relativos al mercado y a los consumidores, ello parece una declaración de voluntad expresa del legislador sobre el bien digno de tutela penal. No obstante, la ubicación sistemática define la intención, pero no determina la exclusividad de la protección.

Al hilo de lo expuesto, no puede olvidarse la diferenciación existente entre patrimonio y orden socioeconómico. Sin ánimo agotar el tema, sí conviene hacer una breve referencia al asunto, debido a las dudas generadas por el mismo entre los especialistas: se ha sostenido que los delitos contra el orden socioeconómico afectan al orden económico de la sociedad ${ }^{16}$, distinguiéndose así de los patrimoniales que comprometen bienes individuales; lo anterior, empero, sin perjuicio de aceptar la existencia de una protección de bienes individuales orientada a la tutela de bienes mediatos supraindividuales (Martínez-Buján, 2015, p. 207). En el mismo sentido, se ha matizado que la principal tarea de los delitos económicos -que de manera directa o indirecta protegen bienes jurídicos colectivos-es tipificar adecuadamente comportamientos que, de forma individualizada, tienen una lesividad social cualificada que justifica la intervención penal (Feijóo, 2008, p. 151).

Pese a lo dicho, lo cierto es que el CP da lugar a una cierta confusión, pues, la expresión 'orden socioeconómico' es difusa y está cargada de indefinición (Borja, 2015, p. 331); además, existen delitos que podrían considerarse de naturaleza socioeconómica que están fuera del Título XIII (p. ej., los de financiación ilegal de partidos o contra la Hacienda Pública y la Seguridad Social) y hay otros que, estando incluidos en él, plantean serias dudas en cuanto a su naturaleza socioeconómica o patrimonial (Martínez-Buján, 2015, p. 207). La solución que

\footnotetext{
${ }^{16}$ Se puede definir como la participación estatal en la economía o como el conjunto de normas protectoras de la distribución, producción y consumo de bienes y servicios. Así, Borja (2015), quien considera el orden socioeconómico como "los intereses generales que cimientan la estabilidad de la economía de forma general” (pp. 333-334), aunque realiza una acertada reflexión sobre la posibilidad de afectación al orden socioeconómico a través de un delito patrimonial, según las circunstancias en las que se materialice, $v$. gr., una estafa a miles de personas o la insolvencia punible de una entidad financiera.
} 
parece ser más adecuada es la de analizar el bien jurídico en cada figura delictiva para poder diferenciarlos con mayor claridad y, de paso, resolver supuestos de concursos de leyes penales o de infracciones (Vidales, 1998, p. 371).

\section{Las teorías eclécticas.}

No toda la doctrina penal ha reconocido los intereses económicos como el único objeto de tutela en el delito de publicidad engañosa. La cuestión es, entonces, si lo protegido mediante la incriminación del delito en comento es el interés económico de los consumidores o, también, otros bienes reconocidos en la CE tales como, v. gr., la salud.

Ya hemos señalando las opiniones de algunos que se decantan por el aspecto económico descartando lo atinente a la salud, por cuanto el CP tiene un apartado específico donde se castigan los delitos que suponen un peligro para la misma (Martínez-Buján, 2015, p.294), aunque referidos a los alimentos o a los medicamentos -arts. $362-1-3^{\circ}, 363-1$ y 363-4 inciso $2^{\circ}-$.

La interpretación anterior conlleva un problema, pues hay supuestos en los que se puede afectar la salud sin que se trate de alimentos ni de medicamentos, p. ej., cuando se publicita un tejido de un determinado componente puro que en realidad no lo es y que puede generar alergias $\mathrm{u}$ otro tipo de reacciones dermatológicas importantes; otro tanto puede decirse en punto de los productos adelgazantes -no considerados medicamentos- o estéticos (Nieto, 2010, p. 496). En tanto el peligro para la salud en estos supuestos no proviene de alimentos ni de medicamentos, algunos autores entienden que la publicidad engañosa también tutela la salud (Cugat, 2001, p. 1172; Gómez, 1997, p. 1233 y Carrasco, 2000, p. 89).

Sin embargo, las razones que nos hacen inclinarnos por la consideración de una protección de índole puramente económica y descartar, por lo tanto, la salud, no se afincan tan sólo en la ubicación sistemática del delito, sino en la protección económica más general del precepto, es decir, por cuanto la publicidad engañosa tendrá un componente económico en todos los casos. En sentido contrario, no siempre habrá una trascendencia referida a la salud, pues no todos los productos o servicios van a incidir en ella.

Por eso, parece más correcto considerar el bien protegido como de índole únicamente económica; de entender incluida la protección conjunta de lo económico y de la salud, la aplicación del tipo penal exigiría -en orden a respetar el principio de ofensividad (Cobo del Rosal, 1999, pp. 315 y 316)- la causación de un peligro para ambos y, como viene de explicarse, ello no ocurre en todas las hipótesis; en consecuencia, castigar por el delito de publicidad engañosa en tales eventos en los que no hay, en realidad, un peligro para la salud, sería discutible.

La opción de entenderlos protegidos de manera alternativa no es mejor, pues, de nuevo, el interés económico de los consumidores siempre se ve afectado, pero no ocurre lo mismo con la salud; de ahí que resulte verdaderamente difícil imaginar un supuesto donde lo afectado sea lo segundo y no lo primero -la publicidad 
siempre tiene por objeto la venta de productos y ello supone una contraprestación económica-.

No obstante, si consideramos como bien jurídico protegido únicamente el interés económico evitaremos los problemas apuntados, de tal forma que podremos entender acertada la aplicación del tipo penal siempre que se produzca el peligro dicho interés de los consumidores, al margen de que se ponga en peligro o no su salud.

No podemos dejar este apartado relativo al bien jurídico protegido sin referirnos a las decisiones judiciales y al debate sobre el punto en la tramitación parlamentaria del delito en examen.

Por cuanto mira con lo primero, conviene advertir que el objetivo es, simplemente, mostrar cuál ha sido el criterio mantenido por los tribunales españoles, a efectos de lo cual debe advertirse que la jurisprudencia no ha sido uniforme: una línea, considera que el bien jurídico protegido es el derecho de los consumidores a una información veraz (Juzgado Provincial 23 de Madrid, Sentencia 9 de 2001; Audiencia Provincial de Barcelona, Secc. $9^{\text {a }}$, sentencia de 30 de noviembre de 2005); otra, se inclina por considerar que se protegen los intereses económicos colectivos de los consumidores, aunque dicho interés se conduce al patrimonio (Audiencia Provincial de Toledo, sentencia 1229 de 2000 y Audiencia Provincial de La Rioja, sentencia 17 de 2003); y, la última, considera que no solo se protege un interés económico sino, también, la salud (Audiencia Provincial de Barcelona, sentencia de 30 de noviembre de 2005).

En cuanto a lo segundo, es importante recordar que el Grupo Popular proponía su supresión, porque dichos coportamientos ya estaban sancionados, suficientemente, por la vía administrativa y porque esas conductas se podían castigar a través de la estafa y los delitos contra la salud pública.

A la suficiencia de la sanción administrativa hemos de replicar diciendo que el de publicitar productos y servicios de forma engañosa es un acto permanente y de gran incidencia en el comportamiento de los consumidores, quienes se ven abocados a situaciones de absoluta manipulación que vician su voluntad (Ripoll, 1991, p. 996). Este argumento, sumado a la descripción típica del artículo 282 CP que establece el posible perjuicio como 'grave y manifiesto', habla a favor de la intervención penal.

Por otro lado, la experiencia práctica en punto del resarcimiento del consumidor por los actos de publicidad engañosa son desalentadores: en el ámbito civil, el artículo 29 de la Ley General de Publicidad 34 / 1988 establece que las controversias sobre publicidad ilícita, dentro de la que se contempla la engañosa, se ventilarán en un procedimiento de menor cuantía ${ }^{17}$-ahora ordinario-; es decir, un declarativo

${ }^{17}$ Con la anterior Ley de Enjuiciamiento Civil, pues con la actual sería un procedimiento ordinario, pero la referencia es importante pues la aprobación del Código Penal fue bajo la vigencia de la anterior Ley de Enjuiciamiento Civil. 
que puede durar mucho tiempo (Ripoll, 1991, p. 999 y Corredoira, 1993, pp. 100 y ss.) y contra grandes compañías que hacen de la posición del consumidor individual una situación a todas luces desventajosa. La sanción penal resucita la posición teóricamente igualitaria en un proceso de protección por publicidad engañosa.

Por lo que respecta a la sanción mediante la estafa -y / o los delitos contra la salud pública-, los motivos que nos empujan a manifestarnos en contra de tal objeción son dos: por un lado, el ámbito de los delitos contra la salud pública se circunscribe, como ya se expuso, a la tutela de esta última y, por el otro, la estafa requiere dirigir la conducta de forma más particularizada, incluso en el delito masa, mientras que la publicidad engañosa está orientada a todos los consumidores -o a un grupo de ellos- de forma indiscriminada; además, la estafa requiere un resultado, cual es, un acto de disposición que conlleve un perjuicio patrimonial. Se trata, pues, de comportamientos totalmente distintos que protegen a los consumidores en estadios diferentes; la publicidad engañosa lo hará en la fase de peligro para los bienes jurídicos colectivos y la estafa lo hará en la fase de concreción de un perjuicio, en este caso económico, sobre el patrimonio individual.

\section{Conclusiones}

La economía de libre mercado imperante en nuestra sociedad propicia que las empresas tengan la necesidad de comercializar sus bienes y servicios. La técnica más eficaz para llevar a cabo este cometido no es otra que la publicidad, la cual se convierte, por lo tanto, en una herramienta necesaria -y en principio positivapara dar a conocer a los consumidores los diferentes productos y servicios que existen en el mercado.

La publicidad desarrolla unas técnicas muy especializadas que llevan a sugestionar y, en algunos casos, a conducir la conducta de los consumidores a la hora de adquirir los productos y servicios, pero, cuando, además de las técnicas sugestivas y condicionantes, la publicidad es engañosa, la situación de riesgo para los consumidores es importante.

El tránsito del Estado liberal al Estado social supone su mayor intervención en la regulación de los ámbitos económicos y evitar situaciones de desigualdad; este principio hace que el Estado regule la protección de los consumidores, incluyendo lo atinente a la publicidad engañosa. Como consecuencia de ello, coexisten varias disposiciones pertenencientes a otras tantas ramas del derecho, paradigmáticamente, las civiles y las administrativas, pero ambas se revelan insuficientes: las dificultades para que los consumidores accedan a la vía judicial y hagan valer sus derechos son grandes, los costes económicos de un pleito civil y la necesidad de acreditar el perjuicio producido llevan a que el mayor porcentaje de asuntos tramitados sea por la falta de especificación en las condiciones del producto o servicio.

Por ello, la intervención del derecho penal se revela necesaria para evitar esa situación de desventaja en que se encuentran los consumidores a la hora de defender sus derechos y tal protección se canaliza a través del llamado 'derecho penal económico'. 
En este orden de ideas, el bien jurídico protegido es de carácter supraindividual $\mathrm{y}$ viene constituido por el derecho de los consumidores a una información veraz, entendida como un instrumento que protege sus legítimos intereses económicos, atendida su condición de parte en el mercado. Tal protección supondrá mantener el orden económico frente a los ataques más graves para el bien jurídico tutelado.

\section{Referencias}

Aguilera, A. (1981). La protección de los consumidores. Revista de Derecho Mercantil, (161-162), 581-610.

Álvarez, A. (2014). El nuevo panorama de los medios tradicionales: ¿qué hacer con la publicidad? En M. Catalá y O. Díaz (Coords.), Publicidad 360 (pp. 131-145). Zaragoza: Universidad de San Jorge.

Arroyo, L. (1994). Actualidad político criminal del Derecho Penal económico en España. En Estudios de Derecho Penal económico (pp. 15-24). Castilla-La Mancha.

Bajo, M. (1995). Derecho Penal Económico: desarrollo económico, protección penal y cuestiones político/criminales. En Hacia un Derecho Penal Económico Europeo. Jornadas en honor del Profesor Klaus Tiedemann (pp. 63-80).

Bajo, M. (2013). Los delitos económicos como manifestación característica de la expansión del derecho Penal. En F. J. Álvarez (Coord.) Libro homenaje al Profesor Luis Rodríguez Ramos (pp. 407-416). Madrid: Tirant lo Blanch.

Bajo, M. y Bacigalupo, S. (2001). Derecho Penal Económico. Madrid: Centro de Estudios Ramón Areces.

Baudrillard, J. (1989). Publicidad absoluta, publicidad cero. Revista de Occidente, (92), 5-16.

Barbero, M. (1973). Contribución al estudio de los delitos de peligro abstracto. En Anuario de Derecho Penal, (36), 487-300.

Barona, S. (1999). Tutela civil y penal de la publicidad. Valencia: Tirant lo Blanch.

Bassat, L. (2013). El libro rojo de la publicidad (ideas que mueven montañas) (2a ed.). Barcelona: De Bolsillo.

Benavides, J. (2012). La investigación en la comunicación y publicidad: nuevos temas y problemas. Revista internacional de comunicación y publicidad, 1(17), 71-93.

Benavides, J. (2014). La nueva andadura de la publicidad. En M. Catalá y O. Díaz (Coords.) Publicidad 360 (pp. 7-16). Zaragoza: Universidad de San Jorge.

Biedma, J. (1997). Valores de la publicidad y publicidad de los valores. Comunicar: Revista científica iberoamericana de comunicación y educación, (9), 61-68. 
Borja, E. (1995). La terminación del delito. Anuario de Derecho Penal y Ciencias Penales, I (T. XLVIII), 89-186.

Borja, E. (2011). Curso de politica criminal (2a ed.). Valencia: Tirant lo Blanch.

Borja, E. (2015). Delitos contra el patrimonio y el orden socioeconómico (I): Introducción general. En J.L. González (Coord.) Derecho Penal. Parte especial (4a ed., pp. 329-336). Valencia: Tirant lo Blnach.

Bottke, W. (1995). Sobre la legitimidad del Derecho Penal económico en sentido estricto y sus disposiciones típicas específicas. En Hacia un Derecho Penal Económico Europeo. Jornadas en honor del Profesor Klaus Tiedemann (pp. 637-654). Madrid: Boletin Oficial del Estado, BOE

Braidot, N. (2000). Neuromarketing. Barcelona: Ediciones Gestión 2000.

Carbonell, J. (1999). El delito publicitario. En J. Carbonell et al. Derecho Penal. Parte especial ( $3^{\mathrm{a}}$ ed., pp. 524-526). Valencia: Tirant lo Blanch.

Carrasco, M. (2000). La publicidad engañosa y el Derecho Penal (una aproximación al tipo del artículo 282 del C.P.). Valencia: Ediciones Revista General De Derecho.

Cobo del Rosal, M. y Vives, T. (1999). Derecho Penal. Parte General, (5 ed.). Valencia: Tirant lo Blanch.

Corredoira, L. (1993). Comentarios a la Ley de Publicidad. Ley 34/1988 y disposiciones complementarias. Barcelona: Bosch.

Cuerda, A. (1995). Contribución a la polémica sobre el delito publicitario. Estudios sobre consumo, (35), 67-81.

Cuerda, A. (2001). Los medios de comunicación y el Derecho penal. En L. A. Arroyo (Coord.). Homenaje al Dr. Marino Barbero Santos (Vol. 1, pp. 182-206). Cuenca: Universidad de Castilla-La Mancha, Ediciones de la Universidad de CastillaLa Mancha y Universidad de Salamanca.

Cuesta, M. (2014). Éxito en publicidad, cuestión de estadísticas. Revista de estadística y sociedad, (61), 4-6.

Cugat, M. (2001). La protección de intereses colectivos: el caso del delito publicitario. En G. Quintero (Dir.). El nuevo Derecho Penal español. Estudios penales en memoria del Profesor José Manuel Valle Muñiz (pp. 1167-1190). Pamplona: Aranzandi.

Damasio, A. (2005). En busca de Spinoza. Neurobiología de la emoción y los sentimientos (Trad. Joan Domènec Ros). Barcelona: Critica.

De Diego, R. y Díaz, Ó. (2014) Modelos psicológicos sobre comunicación persuasiva. En M. Catalá y O. Díaz. (Coords.) Publicidad 360 (pp. 66-81). Zaragoza: Universidad de San Jorge. 
Demetrio, E. (2005). A propósito del bien jurídico en el delito publicitario tipificado en el artículo 282 del Código Penal español. (Una contribución a partir de una "hermenéutica valorativa") En N. García (Coord.) Protección penal del consumidor en la Unión Europea (pp. 157-1172). Cuenca: Ediciones de la Universidad de Castilla-La Mancha.

De Jesús, M. (1988). La publicidad engañosa como figura típica objeto de criminalización. Poder Judicial, (número especial IX), 313-316.

De Vega, J. (1988). Potección penal del consumidor. Poder Judicial, (número especial IX), 277-297.

Doval, A. y Anarte, E. (2012). Delito publicitario. En J. Boix (Dir.), Derecho Penal. Parte Especial, (Vol. II) (pp. 483-493). Madrid: Iustel.

Feliu, E. (1984). Los lenguajes de la publicidad. Alicante: Universidad de Alicante.

Fernández, A. y Martínez-Buján, C. (1983). Delincuencia y economía. Santiago de Compostela: Universidad de Santiago de Compostela.

Fernández, C. (1989). Estudios de Derecho de la publicidad. Santiago de Compostela: Universidad de Santiago de Compostela.

García, M. y López, D. (1996). El Código Penal de 1995 y la voluntad del legislador. Madrid: Dykinson.

García, N. (1998). Delito ecológico. Estructura y aplicación judicial. Barcelona: Wolters Kluwer Educación.

Gómez, M. (2014). Nuevas tendencias en comunicación publicitaria: En M. Catalá y O. Díaz (Coords.), Publicidad $360^{\circ}$ (pp. 161-175). Zaragoza: Universidad de San Jorge.

Gómez, M. (1997). Hacia una nueva interpretación del delito publicitario. La Ley, (4), 1231-1236.

Gómez, M. (2005). Contribución a la teoría de los delitos de peligro hipotéticoaptitud abstracta. Los delitos de tenencia como paradigma de peligro abstracto puro. En J. Carbonell (Coord.), Estudios penales en homenaje al profesor Cobo del Rosal (pp. 465-482). Madrid: Dykinson.

González, J. (1995). Aproximación a los delitos contra el orden socioeconómico en el proyecto de Código Penal de 1992. En Hacia un derecho penal económico europeo. Jornadas en honor del Profesor Klaus Tiedemann, (pp. 167-186). Madrid: Boletín Oficial del Estado, BOE.

González, J. (1998). Delitos relativos al mercado y a los consumidores. En A. Asúa (Dir.) Jornadas sobre el nuevo Código penal de 1995 (pp. 145-150). Bilbao: Universidad del País Vasco. 
González, J. (2011). Publicidad engañosa. En L. Morillas (Coord.). Sistema de Derecho Penal español. Parte especial (pp. 600-602). Madrid: Dykinson.

González, M. (2010). Protección penal del consumidor: especial consideración al delito de publicidad falsa. En I. Cubillo (Coord.), Cuestiones actuales sobre la protección de los consumidores: tutela penal, civil y arbitral (pp. 75-123). Pamplona: Thomson.

Guía, J. (1998). La publicidad, una teoría difícilmente práctica. Revista Latina de comunicación social, (8), 1-6.

Haas, C. (1971). Teoría, técnica y práctica de la publicidad. Madrid: Rialp.

Hansen, H. (1970). Marketing (Trad. G. Pascual). Barcelona.

Hernández, J. (1997). El delito publicitario. Actualidad Penal, (2), 1095-1118.

Hernández, J. (1997). El delito publicitario. En J. Martín et al. Estudio y aplicación práctica del Código Penal de 1995 (T II, pp. 241-271). Madrid: Centro Superior de Estudios.

Hormazábal, H. (1995). Los delitos socioeconómicos, el bien jurídico, el autor, su hecho y la necesaria reforma del sistema penal español. En Hacia un Derecho Penal Económico Europeo. Jornadas en honor del Profesor Klaus Tiedemann (pp. 187208). Madrid: Universidad Autónoma de Madrid.

Iglesias, M. (2013). Imagen del consumidor y delito de publicidad engañosa. Necesidad y merecimiento de protección. Una aproximación a partir de la reciente interpretación alemana. En F. Álvarez (Coord.). Libro homenaje al Profesor Luis Rodríguez Ramos (pp. 621-654). Valencia: Tirant lo Blanch.

Jiménez, M. (2014). Investigar la publicidad desde sus contenidos. En M. Pérez y Ó. Díaz. (Coords.). Publicidad 360 (pp. 95-114). Zaragoza: Universidad de San Jorge.

Lafuente, P. (2014). Lo social como germen de lo publicitario. En M. Pérez y Ó. Díaz. (Coords.). Publicidad 360 (pp. 82-93). Zaragoza: Universidad de San Jorge.

Lester, B. (1968). Ingeniería de ventas (Trad. S. González). (2 ed.). Bilbao.

López, B. (2007). Publicidad emocional. Estrategias creativas. Madrid: ESIC.

Macías, M. (2012). Análisis criminológico y político criminal del delito de publicidad engañosa. Granada. Recuperado de http: / / hera.ugr.es.

Manzanares, J. (1988). La tipificación del delito publicitario en el Derecho español. Poder Judicial, (Especial IX), 269-276.

Mapelli, B. (1999). El delito de publicidad fraudulenta. Valencia: Tirant lo Blanch. 
Martínez-Buján, C. (1983). Sección segunda del capítulo primero del título XII de la propuesta de anteproyecto de nuevo Código penal de 1983: "De los delitos publicitarios" (arts. 279 y 280)". En Documentación Jurídica 2(37-40), 749-767.

Martínez-Buján, C. (1984). Consideraciones en torno a la creación de un delito relativo a la publicidad engañosa. Cuadernos de Política Criminal (22), 33-94.

Martínez-Buján, C. (1992-1993). Los delitos relativos al mercado y a los consumidores en el proyecto de Código Penal de 1992. Estudios Penales y Criminológicos (16), 327-394.

Martínez-Buján, C. (1995). El delito de publicidad engañosa en el anteproyecto de Código Penal de 1992. En Hacia un Derecho Penal Económico Europeo. Jornadas en honor del Profesor Klaus Tiedemann (pp. 229-241). Madrid: Boletín Oficial del Estado, BOE.

Martínez-Buján, C. (1996). Comentario al artículo 282. En Comentarios al Código Penal de 1995, (Vol. II, pp. 1369-1374). Valencia: Tirant lo Blanch.

Martínez-Buján, C. (2012). Derecho Penal económico. Madrid: Iustel.

Martínez-Buján, C. (2015). Derecho penal económico y de la empresa. Parte especial (5 ed.). Valencia: Tirant lo Blanch.

Martín, J. (2014). Medición de la eficacia publicitaria. En M. Pérez y O. Díaz. (Coords.). Publicidad $360^{\circ}$ (pp. 176-188). Zaragoza: Universidad de San Jorge.

Martos, J. (1987). El principio de intervención mínima. Anuario de Derecho Penal y Ciencias Penales, (XL), 99-134.

Mata y Martín, R. (1997). Bienes jurídicos intermedios y delitos de peligro. Granada: Comares.

Matellanes, M. y Tapia, A. (2014). Cómo investigar para la publicidad actual. En M. Catalá y O. Díaz (Coords.) Publicidad 360 (pp. 115-130). Zaragoza: Universidad de San Jorge.

Meyers, W. (1994). Los creadores de imagen (Trad. Joaquín Adsuar Ortega). Barcelona: Ariel.

Mir, S. (1994). El Derecho penal en el Estado social y democrático de derecho, Barcelona: Ariel.

Mir, S. (2015). Derecho Penal. Parte General (10ª ed.). Barcelona: Reppertor.

Morales, F. (2011). Comentario al art. 282. En G. Quintero (Dir.). Comentarios a la parte especial del Derecho Penal (9a ed., pp. 881-887). Pamplona: Aranzandi 
Moreno, M. (2002). El concepto penal de incendio desde la teoría del caos (Una perspectiva sistémica de los bienes jurídicos colectivos, del peligro y de su causalidad). Valencia: Tirant lo Blanch.

Moreno y Bravo, E. (2001). El delito de publicidad falsa. Barcelona: Bosch.

Muñagorri, I. (1998). La protección penal de los consumidores frente a la publicidad engañosa. Granada: Comares.

Muñiz, J. (2014). La revolución neurocientífica en publicidad y marketing. En M. Catalá y Ó. Díaz (Coords.) Publicidad 360 (pp. 189-204). Zaragoza: Universidad de San Jorge.

Muñoz, F. (2015). Derecho Penal. Parte especial (20ª ed.). Valencia: Tirant lo Blanch.

Nieto, A. (2008). Derecho Penal (económico) europeo. En J. Boix (Dir.). Diccionario de Derecho Penal económico (pp. 416-425). Madrid: Iustel.

Novoa, E. (1982). Reflexiones para la determinación y delimitación del delito económico. Anuario de Derecho Penal y Ciencias Penales, I(XXXV), 43-75.

Octavio de Toledo y Ubieto, E. (1979). Notas para un estudio los fraudes alimentarios en Derecho Penal. Revista de la Facultad de Derecho de la Universidad Complutense, (57), 55-136.

Ogilvy, D. (1990). Ogilvy y la publicidad. (4ª ed., Trad. Diorki Traductores). Barcelona: Folio.

Orts, E. y González, J. (2015). Compendio de Derecho Penal. Parte General, (5ª ed.). Valencia: Tirant lo Blanch.

Pagliaro, A. (1995). Límites a la unificación del Derecho Penal europeo. En Hacia un Derecho Penal Económico Europeo. Jornadas en honor del Profesor Klaus Tiedemann, (pp. 689-696). Madrid: Boletín Oficial del Estado, BOE.

Pignotti, L. (1976). La supernada. Ideología y lenguaje de la publicidad. Valencia: Fernando Torres, D.L.

Portero, M. (2004). El delito publicitario en el Código Penal español. Valencia: Tirant lo Blanch.

Puente, L. (2002). Delitos económicos contra los consumidores y delito publicitario. Valencia: Tirant lo Blanch.

Ratey, J. (2003). El cerebro: manual de instrucciones. Barcelona: Debolsillo.

Reino de España. Sentencia (1997, febrero 24) (RJ 1997 / 1195). Tribunal Supremo.

Reino de España. Sentencia No. 9 (2001, enero 29) EDJ 97500). Juzgado Provincial 23 de Madrid 
Reino de España. Sentencia No. 6690 (2005, noviembre 30). Audiencia Provincial de Barcelona, Secc. $9^{\text {a }}$.

Reino de España. Sentencia No. 1229 (2000, diciembre 15). Audiencia Provincial de Toledo, Secc. $1^{\mathrm{a}}$.

Reino de España. Sentencia No. 17 (2003, febrero 12) EDJ 48968). Audiencia Provincial de La Rioja.

Ripoll, R. (1991). Publicidad engañosa, tratamiento jurídico español y comunitario, La Ley, (3), 996-1.000.

Rodríguez, T. (1994). Delitos de peligro, dolo e imprudencia. Madrid: Centro de Estudios Judiciales, Ministerio de Justicia.

Rodríguez, G. (1981). Los delitos económicos en el proyecto de Código penal. Anuario de Derecho Penal y Ciencias Penales (número extraordinario), 707-719.

Romero, M. (2014). Nuevos medios digitales y sus posibilidades publicitarias. En C. Pérez. y Ó. Díaz (Coords.). Publicidad 360 (pp. 146-160). Zaragoza: Universidad de San Jorge.

Royo, M. (1998). Diferentes aproximaciones conceptuales a la consideración de la publicidad como información de consumo. Quaderns de Treball (73), 1-28.

Royo, M. et al. (1997). Las críticas a la publicidad. Esic Market, (97), 91-105.

Ruiz, E. (1980). Proyecto de ley orgánica de Código Penal. Madrid: Instituto Nacional de Prospectiva.

Ruiz, E. (1999). La reforma penal y la delincuencia económica. Especial referencia a la protección del consumidor. En Eguzkilore: Cuaderno del Instituto Vasco de Criminología, (13), 33-54.

Ruiz, E. (1999). Derecho Penal económico y proceso penal. Eguzkilore: Cuaderno del Instituto Vasco de Criminología, (número extraordinario 13), 253-264.

Sánchez, I. (1997). El nuevo delito publicitario (art. 282 del Código penal). Actualidad Penal, (2), 543-573.

Santaella, M. (1978). Los derechos de información y expresión de consumidores y usuarios. Documentación Jurídica, (18), 411-430.

Santaella, M. (1981). El delito publicitario. Aspectos penales de la comunicación publicitaria. Madrid: Reus.

Sieber, U. (1995). Estado de la evolución y perspectivas del Derecho Penal económico europeo. En Hacia un Derecho Penal Económico Europeo. Jornadas en honor del Profesor Klaus Tiedemann, (pp. 601-620). Madrid: Boletín Oficial del Estado, BOE. 
Sierra, M. (2003). Análisis jurídico-penal de la publicidad engañosa en internet. Valencia: Tirant lo Blanch.

Silva, J. (2006). La expansión del derecho penal. Aspectos de la Política criminal en las sociedades postindustriales, ( $2^{\mathrm{a}}$ ed.). Barcelona: B de F.

Stampa, J. y Bacigalupo, E. (1980). La reforma del Derecho Penal económico español. Revista Jurídica de Cataluña, 79(3), 143-166.

Tallón, J. (1979). Curso de Derecho Publicitario. Valladolid: De Bolsillo.

Tamarit, J. (1990). La tutela penal de los intereses de los consumidores en la actividad publicitaria: problemas fundamentales. Cuadernos de Política Criminal, (41), 321-346.

Tellis, G. y Redondo, I. (2001). Estrategias de publicidad y promoción (Trad. Belló, C. y Villar, I.). Madrid: Addison-Wesley.

Terradillos, J. (1995). Derecho penal de la empresa. Madrid: Trotta.

Tiedemann, K. (1985). Poder económico y delito. Barcelona: Ariel.

Tiedemann, K. (1995). Presente y futuro del Derecho Penal Económico. En Hacia un Derecho Penal Económico. Jornadas en honor del Profesor Klaus Tiedemann (pp. 29-42). Madrid: Boletín Oficial del Estado, BOE.

Torío, A. (1981). Los delitos del peligro hipotético. Anuario de Derecho Penal, (XXXVI), 825-847.

Valle, J. (1996). Comentario al artículo 282 del Código Penal. En G. Quintero (Dir.), Comentarios a la Parte Especial del derecho Penal (pp. 633-638). Pamplona: Aranzandi,

Vázquez, J. (1992). La publicidad correctora: un modelo americano adoptado por la Ley General de Publicidad. La Ley, (2), 923-938.

Vervaele, J. (1991). La Comunidad Económica Europea frente al fraude comunitario ¿hacia un espacio "penal europeo"? Cuadernos de Política Criminal, (43), 119-137.

Vidales, C. (1998). Los delitos socioeconómicos en el Código Penal de 1995: la necesidad de su delimitación frente a los delitos patrimoniales. Estudios Penales y Criminológicos, (XXI), 306-378. 